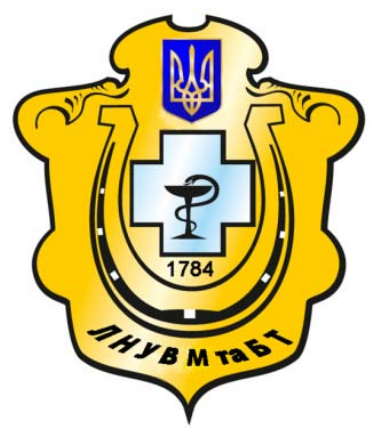

Науковий вісник Львівського національного університету ветеринарної медицини та біотехнологій імені С.3. Гжицького

Scientific Messenger of Lviv National University of Veterinary Medicine and Biotechnologies named after S.Z. Gzhytskyj

doi:10.15421/nvlvet7503

ISSN 2519-268X print

ISSN 2518-1327 online

$\underline{\text { http://nvlvet.com.ua/ }}$

УДК 602.4:[577.15:577.114.4]:635.342

\title{
Характеристика імунотропних функціональних інгредіснтів бактеріального походження, отриманих шляхом фізичного впливу
}

\author{
A.I. Капустян \\ onaft_foodtechn@mail.ru \\ Одеська національна академія харчових технологій, \\ вул. Канатна, 112, м. Одеса, 65039, Україна
}

\begin{abstract}
Зазначено, що складові пептидогліканів клітинних стінок бактерій, у тому числі молочнокислих, володіють високою функиіонально-фізіологічною активністю і є вельми перспективними харчовими імунотропними інгредієнтами. Доцільною $\epsilon$ деструкиія бактеріальних клітин з метою отримання біологічно активних сполук, здатних легше засвоюватися $і$ вступати в біохімічні прочеси, прискорюючи очікуваний імунотропний ефект.

У роботі вивчено вплив фізичних дезінтегруючи факторів, а саме, ультразвуку та мікрохвиль НВЧ, на ефективність деструкиї клітинних стінок Lactobacillus acidophilus. Надано порівняльну характеристику дезінтегратів бактеріальноі маси (БМ) Lactobacillus acidophilus, отриманих із застосуванням ультразвуку та мікрохвиль НВЧ. Показано, шо більш ефективним методом фізичної деструкиї бактеріальних клітин є обробка ультразвуком. Встановлено молекулярномасовий розподіл сполук білкової природи та вміст незамінних амінокислот у складі дезінтеграту, отриманого шияхом обробки БМ ультразвуком.

Ключові слова: дезінтеграт, Lactobacillus acidophilus, пептидоглікан, ультразвук, мікрохвилі надвисокої частоти, функиіональні інгредієнти.
\end{abstract}

\section{Характеристика иммунотропных функциональных ингредиентов бактериального происхождения, полученных путем физического воздействия}

\author{
А.И. Капустян \\ onaft_foodtechn@mail.ru
}

Одесская национальная академия пищеевых технологий,

ул. Канатная, 112, Одесса, Одесская область, 65039, Украина

\begin{abstract}
Отмечено, что составляющие пептидогликанов клеточных стенок бактерий, в том числе молочнокислых, обладают высокой функиионально-физиологической активностью и являються весьма перспективными пищевыми иммунотропными ингредиентами. Целесообразна деструкиия бактериальных клеток с целью получения биологически активных соединений, способных легче усваиваться и вступать в биохимические процессы, ускоряя ожидаемый иммунотропный эффект.

В работе изучено влияние физических дезинтегрирующие факторов, а именно, ультразвука и микроволн СВЧ, на эффективность деструкции клеточных стенок Lactobacillus acidophilus. Представлена сравнительная характеристика дезинтегратов бактериальной массы (БМ) Lactobacillus acidophilus, полученных с применением ультразвука и микроволн СВЧ. Показано, что более эффективным методом физической деструкиии бактериальных клеток является обработка ультразвуком. Установлено молекулярно-массовое распределение соединений белковой природы и содержание незаменимых аминокислот в составе дезинтеграта, полученного путем обработки БМ ультразвуком.

Ключевые слова: дезинтеграта, Lactobacillus acidophilus, пептидогликан, ультразвук, микроволны сверхвысокой частоты, функииональные ингредиенты.
\end{abstract}

\section{Citation:}

Kapustian, A. (2017). Characterization of the bacterial origin immunotropic functional ingredients obtained through a physical impact. Scientific Messenger LNUVMBT named after S.Z. Gzhytskyj, 19(75), 13-18. 


\title{
Characterization of the bacterial origin immunotropic functional ingredients obtained through a physical impact
}

\author{
A. Kapustian \\ onaft_foodtechn@mail.ru \\ Odesa National Academy of Food Technologies, \\ Kanatna Str., 112, Odesa, 65039, Ukraine
}

It is noted, that the peptidoglycans components of bacteria cell walls, including the lactic acid bacteria, have a highly functional and physiological activity and are very perspective immunotropic food ingredients. It is reasonable the destruction of bacterial cells to obtain biologically active compounds. They can easily assimilate and join biochemical processes thus speeding the expected immunotropic effect. The effect of physical disintegrating factors, namely, ultrasound and microwave, on the efficiency of Lactobacillus acidophilus cell walls destruction was studied in the paper. The efficiency of destruction was determined by the accumulation in the disintegrate of low molecular weight peptides (with molecular weight up to $1500 \mathrm{Da}$ ), amino acids and soluble protein. Microwave treatment of the Lactobacillus acidophilus suspension was carried out by microwave radiation in a microwave frequency field of $2.45 \mathrm{GHz}$ with an emission intensity of 40,60,80 and 100\%. The treatment time was varied in the range 60-300 s. Ultrasound bath PSB-1335-05 with an operating frequency of 15, 25 and $35 \mathrm{kHz}$ was used to process the suspension by ultrasound, the processing time varied in the range of 60 to $900 \mathrm{~s}$.

The results of the studies showed that the most significant disintegrate effect on BM Lactobacillus acidophilus when processed by microwave waves occurred with the application of radiation intensity of $80 \%$ for $300 \mathrm{~s}$, with sonication - using a frequency of $25 \mathrm{kHz}$ for $900 \mathrm{~s}$. The number of amino acids in the disintegrates is 0.27 and $0.59 \mathrm{mg} / \mathrm{cm}^{3}$, respectively. The number of low molecular weight peptides in disintegrates is insignificant.

Thus, it is shown, that more effective method of bacterial cells physical destruction is sonication. The molecular mass distribution of protein compounds and the content of essential amino acids in the disintegrant composition obtained by ultrasound treatment of biomass have been established.

Key words: disintegrate, Lactobacillus acidophilus, peptidoglycan, ultrasound, high frequency microwaves, functional ingredients.

\section{Вступ}

Жвавий інтерес серед дослідників викликає вивчення процесів деструкції бактеріальних клітин 3 метою отримання їхніх біологічно активних складових. Одними із важливих компонентів бактерій є сполуки мурамілпептидного ряду, які входять до складу пептидогліканів клітинних стінок (рис. 1).

Мурамілпептид (МДП) і його похідні, молекулярна маса яких знаходиться в діапазоні 400-1500 Да, мають широкий спектр біологічних ефектів, найбільш важливим 3 яких є імунотропна дія. Сполуки мурамілпептидного ряду сприяють посиленню функціональних властивостей фагоцитів, продукції прозапальних цитокінів, необхідних для ініціації гуморального і клітинного імунітету, що забезпечує стимуляцію природних захисних реакцій організму (Traub, 2006; Qingshan, 2012).

Ключовим молекулярним механізмом взаємодії імунної системи 3 нормальною мікробіотою $є$ розпізнавання розчинних мікробних продуктів імунокомпетентними рецепторами. Сигналами для запуску адаптивной імунної відповіді є не живі бактерії, а їхні фрагменти або продукти життєдіяльності, які досягають клітин імунної системи, проходячи через епітелій. Тому використання цілих мікробних клітин в якості харчових фізіологічно функціональних імунотропних інгредієнтів є малоефективним (Kapustyan and Cherno, 2015).

У зв'язку з цим доцільною є спрямована часткова деструкція бактеріальних клітин 3 метою отримання біологічно активних функціональних харчових інгредієнтів 3 молекулярною масою до 1500 Да, здатних легше засвоюватися і вступати в біохімічні процеси, прискорюючи очікуваний імунотропний ефект.

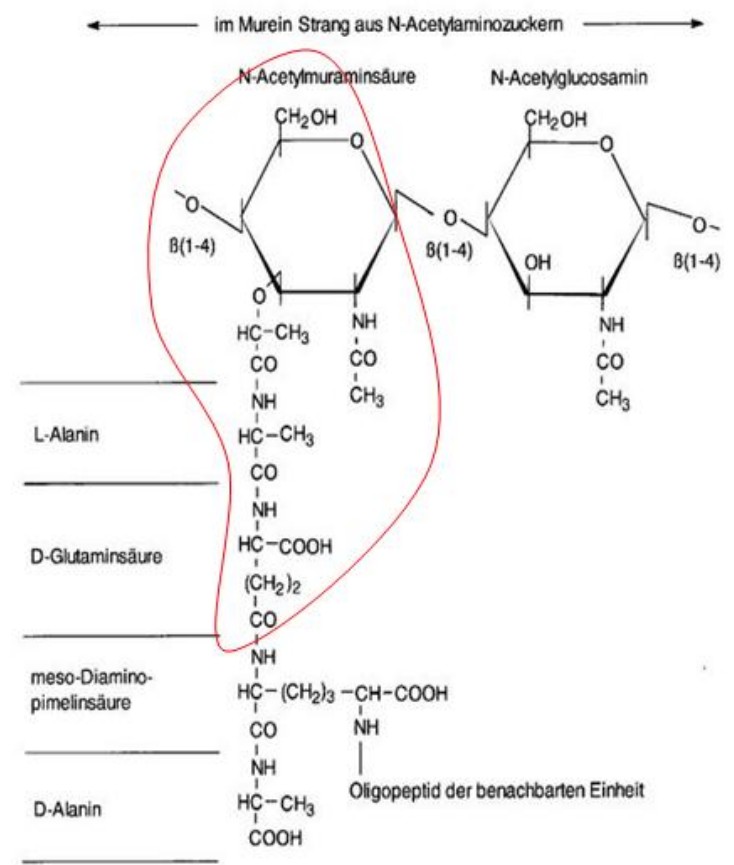

Рис. 1. Фрагмент молекули пептидоглікану клітинних стінок бактерій і МДП у його складі

Викликає інтерес використання для таких цілей молочнокислих бактерій (МКБ), оскільки накопичено значний досвід їхнього культивування для отримання еубіотичних лікарських засобів і дієтичних добавок. До того ж, МКБ мають «GRAS» (Generally Recognized 
As Safe) статус, що визначає їх як абсолютно безпечні для здоров'я людини (Cherno and Kapustyan, 2016).

Загальновідомо, що клітинні стінки мікроорганізмів, особливо грампозитивних, володіють високою механічною міцністю, що зумовлює застосування комбінації різних методів дезінтеграції. Серед сучасних методів деструкції виділяють наступні: фізичні, механічні, хімічні, ензиматичні, біологічні та комбіновані. До найбільш поширених фізичних та механічних методів деструкції відносять обробку ультразвуком, розчалювання замороженої клітинної маси, розтирання у ступці, осмотичний шок, заморожуваннявідтавання, декомпресію (стиснення 3 подальшим різким зниженням тиску) (Shaphaev et al., 2015). В останні роки активно проводяться дослідження щодо можливості руйнування клітинних структур рослинного та мікробного походження із застосуванням мікрохвиль надвисокої частоти (НВЧ) (Zhou et al., 2010).

Як правило, фізична дезінтеграція мікробних клітин призводить до незворотного порушення їхньої анатомічної цілісності. Для отримання глікопептидних низькомолекулярних продуктів регулярної будови, як правило, використовують хімічні та ензиматичні методи деструкції дезінтегратів, отриманих шляхом фізичного впливу на бактеріальну клітину. Такий порядок обробки при отриманні глікопептидних продуктів обумовлено низькою ефективністю деструкції клітин при застосуванні тільки одного із вищеперерахованих методів. Саме тому рекомендовано спочатку застосовувати фізико-механічні методи дезінтеграції мікробних клітин з метою їхньої первинної деструкції та руйнування зовнішніх захисних бар'єрів бактеріальних клітин, які перешкоджають контакту специфічних зв'язків у структурах пептидогліканів 3 дезінтегруючими факторами хімічних та ензиматичних методів впливу.

Застосування комбінованих методів деструкції бактеріальних клітин 3 метою отримання фрагментів їхніх клітинних стінок досліджувалось у ряді робіт.

Так, в роботі (Gavrilin et al., 2007) здійснювали гідроліз Lactobacillus bulgaricus послідовною обробкою пепсином, лізоциму i ультразвуком. У праці (Senchenko et al., 2005) отримано гідролізат молочнокислих бактерій штаму L. acidophilus У 2505 термокислотним методом. Існує також спосіб отримання препарату (Garanyan et al., 2010), що містить глікопептиди, який передбачає напрацювання біомаси клітин L. bulgaricus на спеціальних поживних середовищах, обробку біомаси трипсином, дезінтеграцію біомаси ультразвуком, повторну обробку біомаси трипсином і пепсином, центрифугування, гідроліз лізоцимом, хроматографію.

Але відсутність системного підходу до порівняльної характеристики методів фізичного впливу на бактеріальний субстрат не дозволяе зробити висновок про доцільність використання певного методу для отримання фрагментів клітинних стінок.

Роботу присвячено порівняльній характеристиці дезінтегратів бактеріальної маси (БМ) Lactobacillus acidophilus, отриманих при іiї обробці ультразвуком та мікрохвилями НВЧ, $з$ метою визначення найбільш ефективного методу попередньої часткової деструкції клітинних оболонок бактерій, фрагменти яких у подальшому можуть бути застосовані як джерела низькомолекулярних сполук мурамілпептидного ряду - імунотропних харчових функціональних інгредієнтів

\section{Матеріал та методи досліджень}

Для досліджень використовували БМ Lactobacillus acidophilus iз колекції НВП «Аріадна», м. Одеса із концентрацією $7 \cdot 10^{9} \mathrm{KУO} / \mathrm{cm}^{3}$. Виділення клітин 3 культуральної рідини здійснювали шляхом центрифугування протягом 15 хв при 8000 хв$^{-1}$. Осад клітин відмивали дистильованою водою та ресуспендували. Для фізичної дезінтеграції використовували суспензію клітин Lactobacillus acidophilus у дистильованій воді, вміст сухих речовин суспензії складав $4,78 \pm 0,02 \%$. НВЧ-обробку суспензії Lactobacillus acidophilus здійснювали мікрохвильовими променями в надвисокочастотному електричному полі частотою 2,45 ГГц із інтенсивністю випромінювання 40, 60, 80 та $100 \%$. Тривалість обробки варіювали в інтервалі 60-300 с. Для обробки суспензії ультразвуком використовували ультразвукову ванну ПСБ-1335-05 3 робочою частотою 15,25 та 35 кГц, тривалість обробки варіювали в інтервалі 60-900 с.

В отриманих дезінтегратах контролювали вміст вільних амінокислот методом формольного титрування (Semak et al., 2007), розчинного білка методом Бенедикта (Semak et al., 2007), низькомолекулярних пептидів (НМП) - методом Бенедикта після осадження високомолекулярних білків $10 \%$ розчином трихлороцтової кислоти, кількість нерозчинного осадусушінням до постійної маси при температурі $105^{\circ} \mathrm{C}$. Паралельно визначали відповідні параметри для контрольного зразка- суспензії клітин Lactobacillus acidophilus, яку не піддавали фізичному впливу.

Молекулярно-масовий склад суміші сполук білкової природи дезінтеграту визначали за допомогою гель-хроматографії на колонках з сефадексом G-15 та G-150. Колонку G-15 калібрували маркерами з відомою молекулярною масою, а саме: I - ГМДП (ММ 650 Да), II - аспартам (L-Аспартил-L-фенилаланин, MM 294 Да), III - гліцин (MМ 75 Да). Колонку G-150 калібрували маркерами I - фосфорилаза (97 кДа), II бичачий сироватковий альбумін (65 кДа), III - яєчний альбумін (45 кДа), IV - карбогідраза (30 кДа), V лактоальбумін (14 кДа).

\section{Результати та їх обговорення}

Результати досліджень показали, що найбільш вагомий дезінтегруючий вплив на БМ Lactobacillus acidophilus при обробці хвилями НВЧ мав місце із застосуванням інтенсивності випромінювання $80 \%$, при обробці ультразвуком - із застосуванням частоти випромінювання 25 кГц. За інших параметрів обробки БМ показники ефективності дезінтеграції, тобто збільшення кількості вільних амінокислот, розчинного білка та низькомолекулярних пептидів - не суттєво відрізнялись від показників контрольного досліду (БМ без застосування фізичних методів дезінтеграціі). 
Результати дезінтеграції БМ Lactobacillus acidophilus за найбільш ефективними режимами наведено у табл. 1. Дані таблиці свідчать, що фізичний вплив на клітини навіть при мінімальній тривалості процесу має дезінтегруючу дію, про що свідчить дос- товірне збільшення кількості вільних амінокислот і розчинного білка у всіх дослідних зразках у порівняні 3 контрольним. При цьому має місце зменшення кількості нерозчинного осаду. Характеристика дезінтегратів біомаси Lactobacillus acidophilus, отриманих шляхом обробки ультразвуком та мікрохвилями НВЧ, $(\mathrm{n}=3, \mathrm{P} \leq 0,05)$

\begin{tabular}{|c|c|c|c|c|c|}
\hline \multirow{2}{*}{\multicolumn{2}{|c|}{ Спосіб обробки }} & \multicolumn{4}{|c|}{ Характеристика дезінтеграту } \\
\hline & & $\begin{array}{c}\text { Амінокислоти, } \\
\text { мг/см }{ }^{3}\end{array}$ & $\begin{array}{l}\mathrm{HМ \Pi ,} \\
\mathrm{M \Gamma} / \mathrm{cm}^{3}\end{array}$ & $\begin{array}{c}\text { Розчинний білок, } \\
\text { мг } / \mathrm{cm}^{3}\end{array}$ & $\begin{array}{c}\text { Нерозчинний } \\
\text { осад, } \%\end{array}$ \\
\hline \multicolumn{2}{|c|}{ Контроль (БМ L.a.) } & 0,12 & 0,01 & 1,84 & 4,78 \\
\hline \multirow{3}{*}{$\begin{array}{c}\text { Обробка ультразву- } \\
\text { ком } 3 \text { частотою } 25 \\
\text { кГц }\end{array}$} & $60 \mathrm{c}$ & 0,19 & 0,02 & 1,91 & 4,72 \\
\hline & $300 \mathrm{c}$ & 0,41 & 0,03 & 2,45 & 4,51 \\
\hline & $600 \mathrm{c}$ & 0,57 & 0,01 & 2,74 & 4,11 \\
\hline \multirow{4}{*}{$\begin{array}{c}\text { Обробка НВЧ з } \\
\text { інтенсивністю } 80 \%\end{array}$} & $60 \mathrm{c}$ & 0,14 & 0,01 & 1,88 & 4,76 \\
\hline & $120 \mathrm{c}$ & 0,18 & 0,01 & 1,90 & 4,74 \\
\hline & $180 \mathrm{c}$ & 0,23 & 0,01 & 2,23 & 4,68 \\
\hline & $300 \mathrm{c}$ & 0,24 & 0,01 & 2,26 & 4,61 \\
\hline
\end{tabular}

Максимальне накопичення вільних амінокислот у дезінтеграті, отриманому з використанням ультразвуку у досліджуваному інтервалі тривалості процесу, має місце при обробці протягом 900 с та становить $0,59 \mathrm{мг} / \mathrm{cm}^{3}$. Максимальне накопичення вільних амінокислот у дезінтеграті, отриманому при використанні мікрохвиль НВЧ становить $0,27 \mathrm{Mг} / \mathrm{cm}^{3}$ та тривалості процесу 300 с. У такому випадку кількість амінокислот у дезінтеграті після обробки клітин ультразвуком, порівняно 3 обробкою мікрохвилями НВЧ на 55\% вища. Накопичення вільних амінокислот у дезінтеграті при обробці ультразвуком зі збільшенням тривалості процесу від 600 до 900 с збільшується несуттєво, тому раціональною є обробка суспензії ультразвуком Lactobacillus acidophilus протягом 600 с при частоті 25 кГц. Накопичення НМП, що в основній мірі відповідають за імунотропні властивості структурних компонентів бактеріальних клітин, є незначним у всіх варіаціях процесів дезінтеграції. Максима-

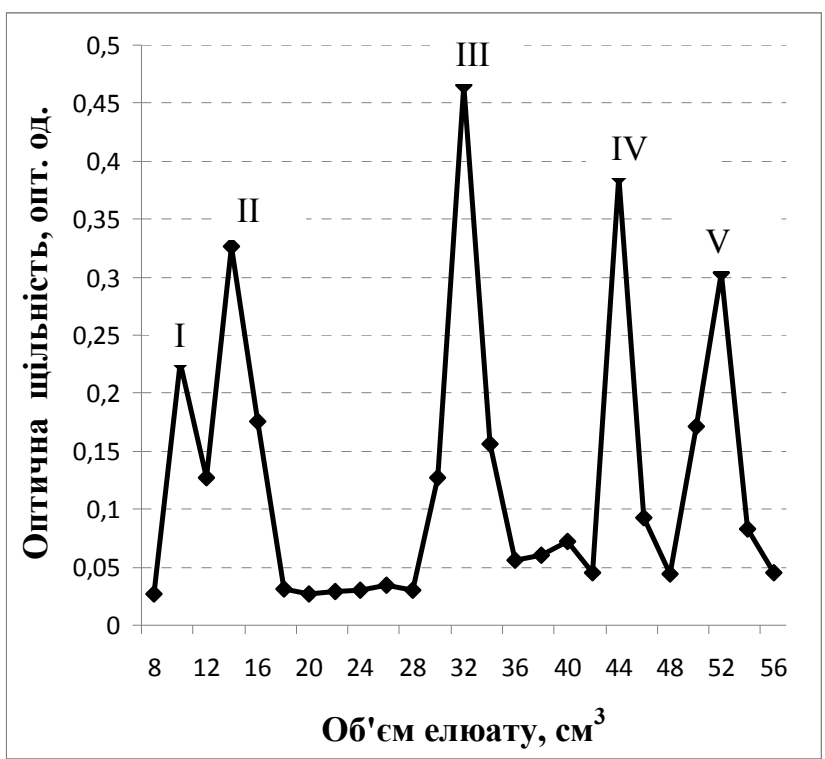

а) Крива гель-хроматографії з маркерами льне накопичення НМП має місце при обробці БМ ультразвуком протягом 300 с і становить $0,03 \mathrm{мг} / \mathrm{cm}^{3}$.

На наступному етапі визначали молекулярномасовий склад суміші сполук білкової природи дезінтеграту, отриманого при обробці БМ ультразвуком протягом 300 с $з$ метою детекції детекції структурних компонентів клітинних стінок БМ, що відповідають молекулярній масі сполук мурамилпептидного ряду (до 1500 Да).

Результати досліджень рідкої фази дезінтеграту показали (рис. 2б) наявність в ній трьох основних фракцій білкової природи, про що свідчить присутність на гель-хроматографічній кривій трьох чітких піків, які відповідають фракціям 3 молекулярною масою в межах 70-90 кДа, 30-40 кДа та фракція, молекулярна маса якої менша за 14 кДа (рис. 2a).

Для більш детального дослідження останньої фракції, на наступному етапі досліджували молекулярномасовий розподіл НМП (рис. 3).

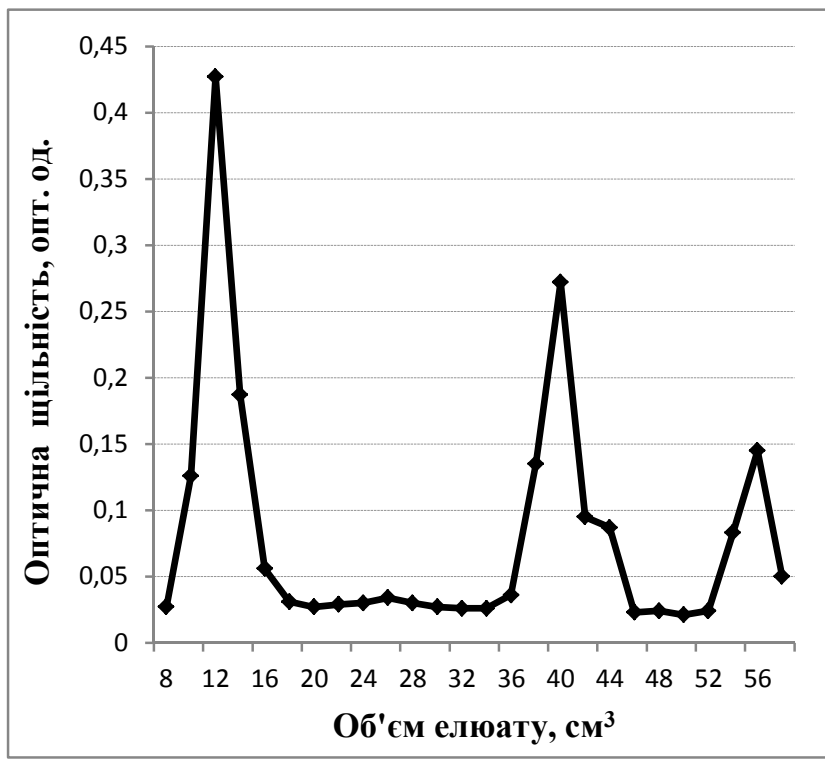

б) Крива гель-хроматографії дезінтеграту

Рис. 2. Молекулярно-масовий розподіл високомолекулярних сполук білкової природи на колонці з сефадексом G-150 


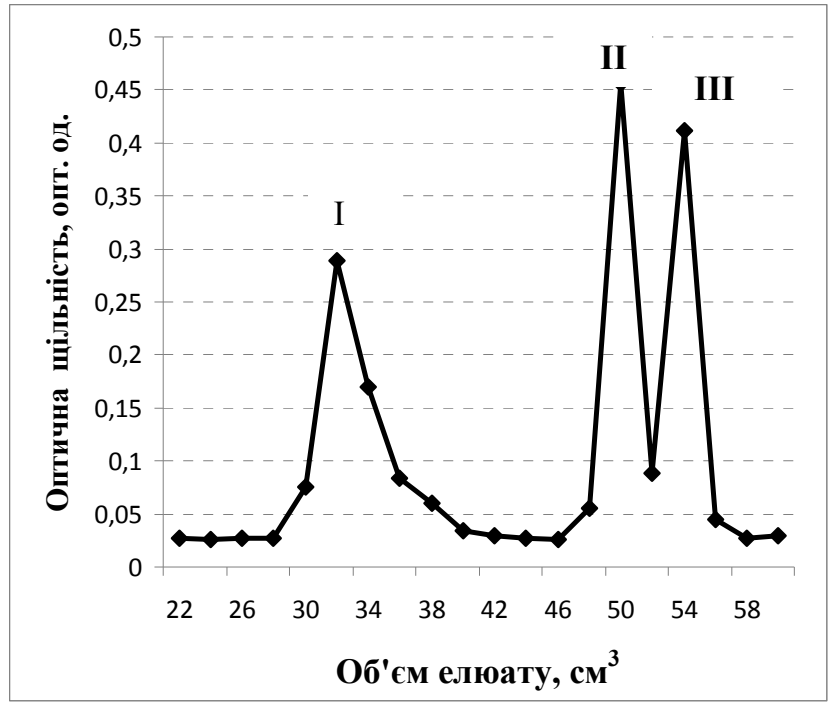

а) Крива гель-хроматографії з маркерами

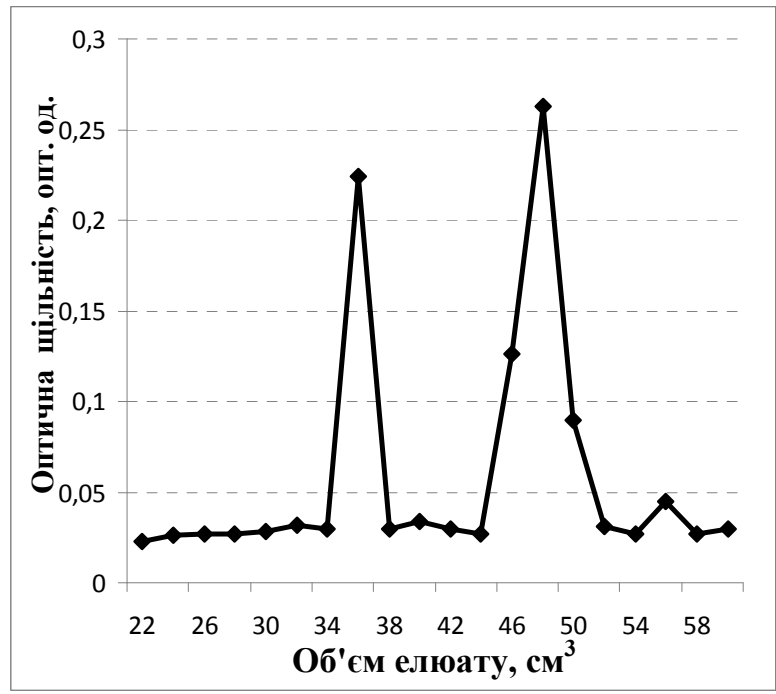

б) Крива гель-хроматографії НМП дезінтеграту

Рис. 3. Молекулярно-масовий розподіл низькомолекулярних пептидів на колонці з сефадексом G-15

На гель-хроматографічній кривій низькомолекулярної фракції дезінтеграту (рис. 3б) присутні два виражених піки на 36-му, 50-му см ${ }^{3}$ елюатів, які знаходяться між піками маркерів 3 молекулярними масами 294-650 Да (рис. 3a). Результати досліджень дозволяють констатувати, що у складі дезінтеграту присутні пептиди 3 молекулярною масою у діапазоні, що відповідає молекулярній масі МДП, але їхня кількість $\epsilon$ досить незначною (табл. 1).

Отже, у складі отриманого дезінтеграту переважають високомолекулярні фракції продуктів білкової природи, які доцільно піддавати подальшим перетворенням із метою отримання продуктів деградації 3 більш високим вмістом НМП. Детальна характеристика молекулярно-масового розподілу сполук білкової природи у складі дезінтеграту, дозволить обгрунтувати спосіб та параметри його хімічної або біохімічної обробки для отримання НМП регулярної будови.

Із метою прогнозування фізіологічнофункціональних властивостей бактеріальних дезінтегратів як перспективних харчових інгредієнтів, досліджено якісний та кількісний вміст ессенціальних компонентів - незамінних амінокислот у їхньому складі (табл. 2).

Табличя 2

Вміст незамінних амінокислот у дезінтеграті

\begin{tabular}{|l|c|c|c|}
\hline Амінокислоти & $\begin{array}{c}\text { Концентрація у } \\
\text { гідролізаті } \\
\text { біомаси, мг/г }\end{array}$ & $\begin{array}{c}\text { Добова } \\
\text { потреба, } \\
\text { мг }\end{array}$ & $\begin{array}{c}\text { Забезпечення } \\
\text { добової } \\
\text { потреби, \% }\end{array}$ \\
\hline Лізин & 4,6 & 55 & 8,36 \\
\hline $\begin{array}{l}\text { Фенілаланін+ } \\
\text { тирозин }\end{array}$ & 2,5 & 60 & 4,16 \\
\hline $\begin{array}{l}\text { Лейцин+ } \\
\text { ізолейцин }\end{array}$ & 7,5 & 110 & 6,81 \\
\hline Метіонін & 0,3 & 35 & 0,85 \\
\hline Валін & 3,9 & 50 & 7,8 \\
\hline Треонін & 3,9 & 40 & 9,75 \\
\hline
\end{tabular}

Результати досліджень дозволяють констатувати наявність у складі дезінтеграту семи 3 восьми незамінних амінокислот. Лімітуючою $\epsilon$ амінокислота метіонін, іiі вміст у складі дезінтеграту - 0,3 мг/г, що забезпечує всього $0,85 \%$ від добової потреби людини. Найбільшим вмістом у характеризується амінокислота лізин, iіi концентрація у складі дезінтеграту 4,6 мг/г, що забезпечує $8,36 \%$ від добової потреби людини. Підвищена концентрація лізину у дезінтеграті може провокувати утворення меланоїдинів за термічної обробки, що необхідно враховувати при розробці режимів розроблення технологій дієтичних добавок та продуктів харчування на його основі.

\section{Висновки}

Показано, що обробка бактеріальної маси ультразвуком як перший етап дезінтеграції клітинник стінок бактерій Lactobacillus acidophilus, який зумовлює руйнування зовнішніх захисних бар'єрів бактеріальних клітин, є більш ефективною, ніж застосування 3 цією метою мікрохвиль НВЧ. Надано характеристику та молекулярно-масовий розподіл сполук білкової природи, встановлено склад вільних амінокислот дезінтегратів.

\section{Бібліографічні посилання}

Traub, S. (2006). MDP and other muropeptides - direct and synergistic effects on the immune system. J. Endotoxin Res. 12, 2, 69-85.

Qingshan, Lv. (2012). MDP Up-Regulates the Gene Expression of Type I Interferons in Human Aortic Endothelial Cells. Molecules. 17, 3599-3608. doi:10.3390/molecules17043599

Kapustyan, A.I., Cherno, N.K. (2015). Perspektivy ispol'zovaniya biologicheski aktivnyh bakterial'nyh gidrolizatov dlya nutritivnoj podderzhki naseleniya $\mathrm{s}$ rastrojstvami immunnoj sistemy. Pishchevaya nauka i 
tekhnologiya. 2(31), 18-25. doi: 10.15673/20738684.31/2015.44263 (in Russian).

Cherno, N., Kapustyan, A. (2016). Immunological properties of the bacterial origin compounds. Food science and technology. 10(3), 19-28. doi: http://dx.doi.org/10.15673/fst.v10i3.175

Shaphaev, Eh.G., Cyrenov, V.Zh., Chebunina, E.I. (2015). Dezintegraciya kletok v biotekhnologii. Uchebnoe posobie.-VSGTU, Udan-Udeh (in Russian).

Zhou, B.W., Shin, S.G., Hwang, K., Ahn, J.H. (2010). Hwang Effect of microwave irradiation on cellular disintegration of Gram positive and negative cells. Appl Microbiol Biotechnol. 2010 Jun;87(2):765-770. doi: 10.1007/s00253-010-2574-7.

Gavrilin, M.V., Sen'chukova, G.V., Senchenko, S.P. (2007). Vybor optimal'nyh uslovii polucheniya gidrolizatov molochnokislyh bakterii termokislotnym sposobom. Him.-farm. Zhurn. 41, 2. 54-56 (in Russian)

Senchenko, S.P. Samoilov, V.A., Gostisheva, N.M., Sen'chukova, G.V., Gavrilin, M.V. (2005). Izuchenie sostava preparata, poluchennogo na osnove gidrolizata molochnokislyh bakterii. Him.-farmac. Zhurn. 39, 3,51-55 (in Russian).

Garanyan, G.S., Hanferyan, R.A., Oganesyan, E.T. (2010). Himicheskoe obosnovanii i biologicheskoe issledovanie gidrolizata na osnove kul'tur molochnokislyh bakterii. Him.-farmac. Zhurn. 44, 8, 46-49 (in Russian).

Semak, I.V., Zyryanova, T.N., Gubich, O.I. (2007). Biohimiya belkov: praktikum dlya studentov biol. Fak. spec. 1-31 0101 «Biologiya». Minsk: BGU (in Russian)

Стаття надійшла до редакциї 10.02.2017 